\title{
Morphology of Intestinal Goblet Cells of The Dromedary (Camelus dromedarius)
}

\author{
Mohamed AMA ${ }^{1,2}$, Taha AAM ${ }^{2}$ and Ali AM ${ }^{1}$
}

1. Department of Anatomy, College of Veterinary Medicine, King Faisal University, Al-Ahsa 31982, Kingdom of Saudi Arabia.

2. Department of Anatomy, Faculty of Veterinary Medicine, University of Khartoum- Sudan. Correspondence to Dr. Mohamed AMA. Email: abduseory@hotmail.com.

\section{ABSTRACT}

Morphology of the goblet cells in the intestine of the dromedary (Camelus dromedarius) was carried out by light and electron microscopes. Histologically, the goblet cells appeared as globular or ovoidshaped with basally located flat nuclei. They were dispersed among the columnar cells lining the epithelia of the villi and crypts of Lieberkuhn, and they increased greatly in number towards the rectum. Goblet cells showed positive reaction to (PAS) stain. Ultrastructurally, the scanning electron microscopy showed villi with rough surface which displayed goblet cells and microvilli in the small intestine. In the large intestine, the surface of the mucosal fold was characteristically covered by goblet cells and epithelial cells. The ultrastructure of the goblet cells showed the cell membrane lacked microvilli and the cytoplasm contained numerous large spherical granules of mucin, rough endoplasmic reticulum and mitochondria. The nucleus containing eccentric nucleolus, chromatin and heterochromatin materials.

Key words: dromedary, goblet cells, intestine, morphology

\section{INTRODUCTION}

The Camel (Camelus dromedarius), is one of the basic forms of productive mammals in the countries of North Africa and Near East (Yagil et al., 1994). It well adapted to life in the desert because of their unique metabolic pathways which enable the animals to survive without food and water for a few days (Robert, 2006; Ouajd and Kamel, 2009). The functions of the intestines are to facilitate easy absorption of nutritive materials, and to act as a barrier against bacteria, viruses, toxins, and different antigens (Pabst, 1987). Goblet cells reside throughout the length of the small and large intestines (Deplancke and Gaskin, 2001; Kim and Khan, 2013).

The presence of the goblet cells in the intestine of the camel was reported in a number of studies (Abdel-Magied et al., 1994; Al-Hussany et al., 2014; Korkmaz and Kum, 2016). Abdel-Magied et al. (1994) stated that, in the small intestine, the cells are unicellular exocrine mucous cells, dispersed among the columnar cells of villi and Lieberkuhn crypts epithelium, the apical portion of it becomes distended due to mucigen droplets accumulation as large globules, and the nucleus is irregularly oval or triangular at the base. Moreover, Al-Hussany et al. (2014) described the location of goblet cells nuclei in the large intestine, they were located at the base of the secretory tubules due to the large amount of mucus within the cells.

The scanning electron microscope of the goblet cells in the small intestine of mammals was mention by Taylor \& Anderson (1972). They reported that the mucosa projects into the lumen to form villi consisting mainly of columnar epithelial cells among which few goblet cells are interspersed. The general feature of the goblet cells in the large intestine was described by Mohamed et al. (2013) in the camel, and Yu and Chiou (1997) in the rabbit.

The ultrastructure of the goblet cells was described in several mammalian species including mouse, rat, human and camel (Shearman and Muir, 1960; Florey, 1960; Wischnitzer, 1960; Hayward and Johnston, 1961; Hollmann, 1963; Pitman and Pittman, 1966; Abdel-Mageid et al., 1994.

The objective of this study is to unveil the 
goblet cells in the intestine of the dromedary.

\section{MATERIAL and METHODS}

Samples were obtained from healthy adult she-camels (age 5-11 years) from Albogaa slaughterhouse, Omdurman, Sudan. Tissue samples from small and large intestinal segments were fixed in $10 \%$ neutral buffered formalin. The tissues were processed routinely as described by Bancroft \& Stevens (1990) and embedded in paraffin wax. Sections of about $7 \mu \mathrm{m}$ thick were cut by a rotary microtome. Then, Haematoxylin and Eosin stain (H\&E) was used for the general histology and Periodic Acid Schiff stain (PAS) for polysaccharides.

For scanning electron microscopy, samples about $4 \mathrm{~cm}$ long from the different segments of the intestine were collected immediately after the animals were slaughtered. The samples were longitudinally opened, washed with normal saline. Small specimens were fixed in freshly prepared $2.5 \%$ glutaraldehyde in Millonig's phosphate buffer ( $\mathrm{pH} 7.4$ ). From each specimen, small pieces of tissue of about
$1 \mathrm{~cm} \mathrm{X} 1 \mathrm{~cm}$ were gradually dehydrated by increasing ethanol alcohol concentrations and by critical point drying with liquid $\mathrm{CO} 2$. Dried tissue specimens were placed on an aluminum stub with silver paint, sputtercoated with gold, viewed and photographed in JEOL 840 scanning electron microscope (Robinson and Gray, 1990).

For transmission electron microscopy, smaller tissue pieces $(0.3 \mathrm{~cm} \times 0.3 \mathrm{~cm})$ from those fixed in $2.5 \%$ glutaraldehyde in Millonig's phosphate buffer ( $\mathrm{pH} 7.4)$ were post-fixed in $1 \%$ osmium tetroxide for 1 hour, washed in Millonig's buffer, dehydrated in graded ethanol and propylene oxide series and embedded in Epon. Ultrathin sections of 50$90 \mathrm{~nm}$ were cut with a diamond knife, mounted on uncoated grids and stained first with uranyl acetate and then with lead citrate (Robinson and Gray, 1990). The examination was carried out in Philips XL transmission electron microscope.

\section{RESULTS}

Histologically, the mucosa of the intestine was made of three layers; the epithelium, the lamina propria, and the muscularis mucosa. The epithelium was made of two types of cells; the epithelial cells (enterocytes) and the goblet cells. The goblet cells, scattered between columnar cells that lined the epithelium (Fig. 1) and crypts of Lieberkühn (Fig. 2), were globular to ovoid shaped with flat basally located nuclei. Their cytoplasm was filled with PAS +ve mucin granules (Fig. 3 ). They appeared to increase in the caudal part of the intestine.

Scanning electron microscopy of the mucosa of the segments of the small intestine showed that the surface of the villi contained the goblet cells which were dispersed between enterocytes (Figs. 4, 5). The cell membrane of the goblet cell was lacking the microvilli (Fig. 5).
In the large intestine, the mucosal folds of the caecum and colon were covered by a layer of epithelial cells and a number of goblet cells (Fig. 6). A great number of goblet cells between the epithelial cells were shown in the mucosal folds of the rectum (Fig. 7).

The ultrastructure of the goblet cell in the small and large intestines showed that, the cell membrane of the goblet cells lacked microvilli and their supra-nuclear cytoplasm displayed numerous large spherical granules of mucin with dark and light colors (Figs. 8, 9). The mean diameter of these granules in each of the three segments of the small intestine was $1.6 \pm 0.02 \mathrm{um}, 0.55 \pm 0.06 \mathrm{um}$, and 1.53 $0.15 \mathrm{um}$ in the duodenum, jejunum and ileum respectively and in the segments of the large intestine was $1.17 \pm$ $0.07 \mathrm{um}$ in the cecum, $0.94 \pm 0.07 \mathrm{um}$ in the colon and $0.99 \pm 0.07$ um in the rectum. The rough endoplasmic reticulum and 
mitochondria were observed peripheral to the nucleus (Figs. 8, 9). The nucleus of the goblet cell was irregular in shape but mostly oval. Iwas situated basally and showed eccentric nucleolus, chromatin and heterochromatin. materials (Figs. 8, 9). While the number of the goblet cells increased dramatically towards the caudal part of the large intestine, conspicuously enterocytes decreased in the rectum (Fig. 10).

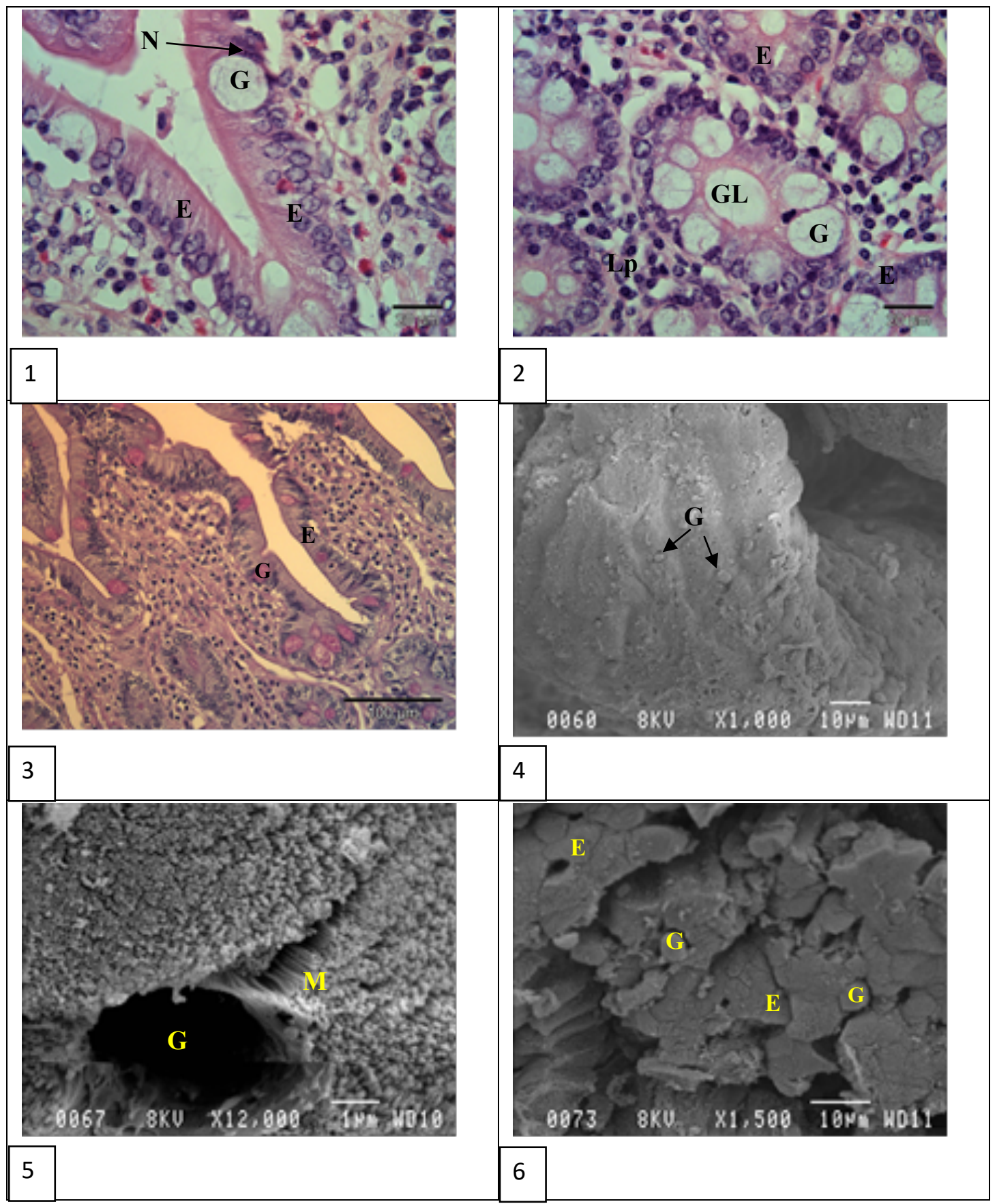




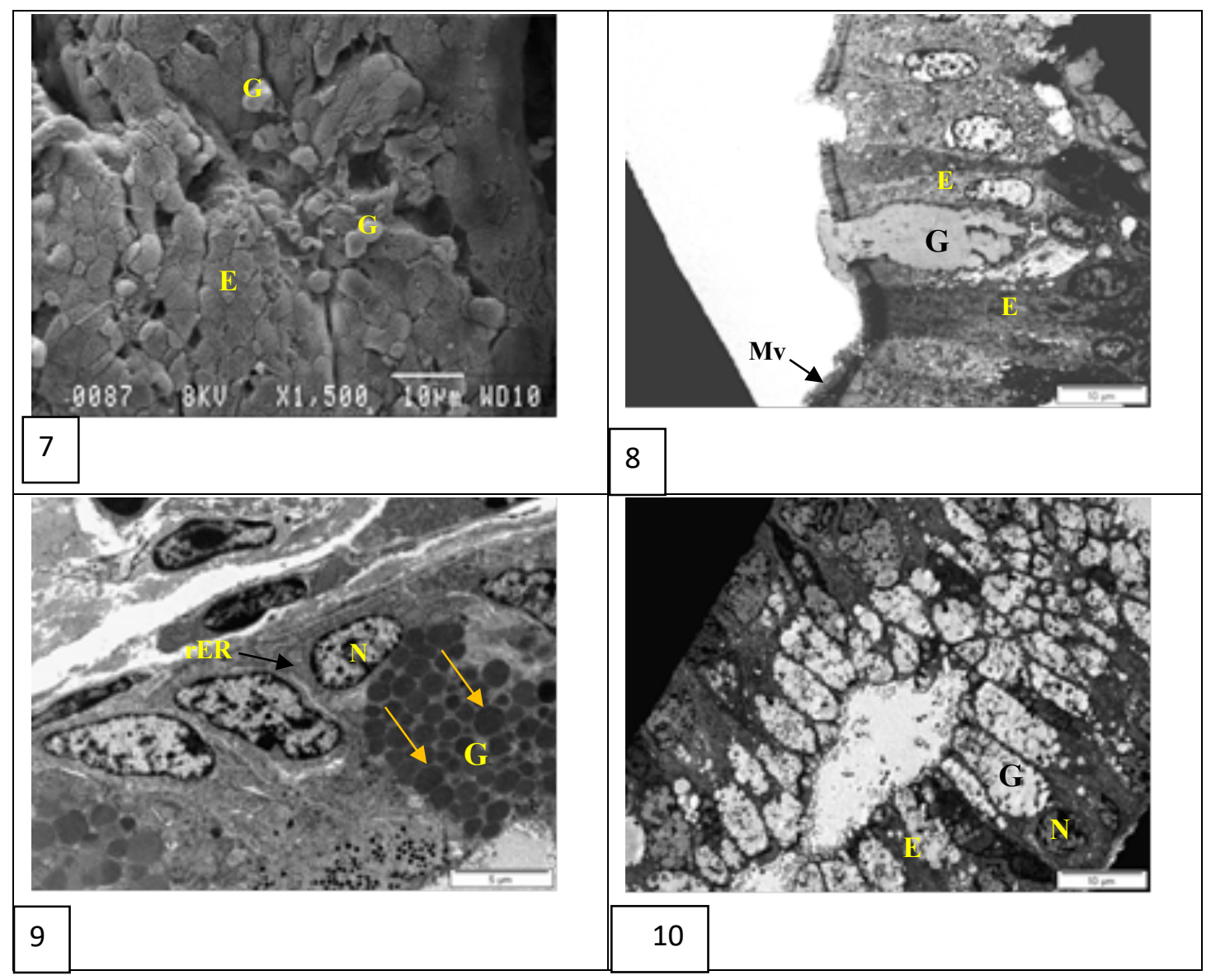

Fig. 1: Light micrograph of the jejunum showing the goblet cells $(\mathbf{G})$, scattered between columnar cells $(\mathbf{E})$ that lined the

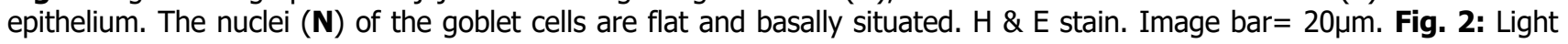
micrograph of the ileum showing the goblet cells $(\mathbf{G})$ and epithelial cells (E) of the gland of Lieberkühn (GL) in the lamina propria. H \& E stain. Image bar= $20 \mu \mathrm{m}$. Fig. 3: Light micrograph of the ileum showing the goblet cells (G) contained +ve PAS mucin granules in their cytoplasm. They were scattered between the enterocytes (E). PAS stain. Image bar= $100 \mu \mathrm{m}$. Fig. 4: Scanning electron micrograph of the villus in the jejunum with high magnification showing the surface of the villus shows goblet cells (G). X1000. Fig. 5: Scanning electron micrograph of a villus in the ileum with high magnification showing the goblet cells (G) and the microvilli (Mv) of the enterocyte at the surface of the villus. X12000. Fig. 6: Scanning electron micrograph of the cecum showing the mucosa displaying epithelial (E) and goblet cells (G). X1500. Fig. 7: Scanning electron micrograph of the rectum showing the epithelial cells (E) with goblet cells (G). X1500. Fig. 8: Transmission electron micrograph of the cecal mucosa showing the goblet cell (G) is present between enterocytes (E). Mv, microvilli. Image bar= $10 \mu \mathrm{m}$. Fig. 9: Transmission electron micrograph of the intestinal gland in the jejunum showing a goblet cell $(\mathbf{G})$ with basally situated flat nucleus (N). Rough endoplasmic reticulum (rER) is present lateral to the nucleus in the goblet cell. The granules of the goblet cell (arrow) are dense and located in the supra-nuclear cytoplasm of the cell. Image bar $=5 \mu \mathrm{m}$. Fig. 10: Transmission electron micrograph of intestinal gland in the rectum showing that the great majority of cells of the intestinal glands are goblet cells (G). Only very few enterocytes (E) are present. The nuclei $(\mathbf{N})$ in both cells are located basally. Image bar $=10 \mu \mathrm{m}$. 


\section{DISCUSSION}

Histological findings of intestinal mucosa in the present study show that the epithelial layer was made of: a- the absorptive ciliated tall columnar cells (enterocytes), b- the goblet cells were scattered between columnar cells. Their nuclei were flat and were basally located and they appeared to increase in number caudally. These observations agreed with that reported by Dellmann and Brown (1976), Banks (1993), Dellmann and Eurell (1998) and Samuelson (2007) in ruminants, Specian and Oliver (1991) in human, and Abdel-Magied et al. (1994), Al-Hussany et al. (2014) in camel. The increasing of the goblet cells number in this study was in line with the main function of the cells. Its known that the function of the goblet cells is production and maintenance of the protective mucus blanket which facilitate the passage of waste matter in the intestine by lubricating the contents (Forstner, 1978; Specian and Oliver, 1991; Kim and Khan, 2013).

In the present study, the scanning electron microscope has been used to examine the mucosal surface of the intestine of the camel. The luminal surface of the small intestine was thrown into transverse folds which were characterized by numerous villi of different shapes and sizes. The surface of the villi contained the goblet cells which were dispersed between enterocytes. While the mucosal folds of the large intestine showed great number of goblet and epithelial cells. This presence of the goblet cells was confirmed by Taylor and Anderson (1972).
In the present study, the electron microscope has revealed the ultrastructure of the goblet cells, the cytoplasm showed numerous and large supra-nuclear spherical granules of mucin, few rough endoplasmic reticulum and mitochondria. The diameter of the mucin granules in ranged from $0.55 \pm 0.06 \mu \mathrm{m}$ to $1.17 \pm 0.07 \mu \mathrm{m}$. These values showed that the size of the granules of the goblet cells in the three segments of the small intestine did follow a certain pattern. They were larger in the duodenum, small in the jejunum and medium size in the ileum. The size of the cytoplasmic granules of the goblet cells in the cecum, colon and rectum followed the same pattern as that of the small intestine, being large in the cecum, small in the colon and medium in the rectum.

The nucleus of the goblet cell was oval in shape, displayed nuclear material, and was located basally. Also, the electron microscope showed the numbers of the goblet cells increased towards the caudal part of the intestine in both the epithelial layer and the intestinal glands.

This ultrastructure of the goblet cells was similar to that described in the mouse, rat, human and camel (Shearman and Muir, 1960; Florey, 1960; Wischnitzer, 1960; Hayward and Johnston, 1961; Hollmann, 1963; Pitman and Pittman, 1966; Abdel-Mageid et al., 1994).

Acknowledgement: Sincere thanks to the staff of the Department of Anatomy and Physiology, Faculty of Veterinary Science, University of Pretoria, South Africa, for their help to execute the practical work. I am also deeply indebted to the College of Veterinary Medicine, Sudan University of Science and Technology, Sudan, for their financial support.

\section{REFERENCES}

1. Abdel-Magied EM, Taha AAM, El-Mougy SA. 1994. The structure of the intestinal villi of the camel (Camelus dromedarius). Vet. Med. J., Giza. 42 (3):121- 126.

2. Al-Hussany BF, Abass Th A, and Al-Medhtiy M. 2014. Histological investigation of the cells in colon, rectum and anal canal of one humped camel (Camelus dromedarius). Magazin of AlKufa University for Biology. 6 (1):1- 12. 
3. Bancroft JD, Stevens A. 1990. Theory and Practice of Histological Techniques. $3^{\text {rd }}$ Ed. Edinburgh: Churchill Livingstone.

4. Banks WJ. 1993. Applied Veterinary Histology. St. Louis. Mosby; $3^{\text {rd }}$ Ed. Edinburgh: Churchil Livingstone.

5. Dellmann HD, Brown EM. 1976. Textbook of Veterinary Histology. Illustrated. Lea \& Febiger. Philadelphia.

6. Dellmann HD, Eurell JA. 1998. Textbook of veterinary histology. $5^{\text {th }}$ Ed. Awoters Kluwer company Philadelphi, Pp: $187-191$.

7. Deplancke B, Gaskins HR. 2001. Microbial modulation of innate defense: goblet cells and the intestinal mucus layer. Am. J. Clin. Nutr. 73:1131S-1141S

8. Florey HW. 1960. Electron microscopic observations on goblet cells of the rat's colon. cells. Quart. J. exp. Physiol., 45, 337-342.

9. Hayward AF, Johnston HS. 1961. The fine structure of the epithelium of the colon in the mouse. Scot. Med. J. 6, 416-425.

10. Hollmann KH. 1963. The fine structure of the goblet cells in the rat intestine. Ann. N. Y.

11. Kim JJ, Khan WI. 2013. Goblet Cells and Mucins: Role in Innate Defense in Enteric Infections. Pathogens. 2, 55-70.

12. Korkmaz D, Kum S. 2016. Histological study of the small intestine of the dromedary. Journal of Camel Practice and Research. 23 (1): 111- 116.

13. Mohamed AMA, Taha AAM, Ali AM. 2013. Scanning electron microscopy of the mucosa of the large intestine of the camel (Camelus dromedarius). Journal of Camel Practice and Research. 20 (2): 187-189.

14. Ouajd S, Kame B. 2009. Physiological particularities of dromedary (Camelus dromedarius) and experimental implications. J Lab Anim Sci 36:19-29

15. Pabst R. 1987. The Anatomical Basis for the Immune Function of the Gut. Anat. Embryol. 176 (2): 135- 144.

16. Pittman FE, Pittman JC. 1966. An electron microscopic study of the epithelium of normal human sigmoid colonic mucosa. Gut, 7, 644- 661.

17. Robert N. 2006. New World camelids:Basic anatomy and pathology, Plenary paper :Wildlife , Session3B , ESVP Edinburgh, Scotland: $26-30$.

18. Robinson G, Gray T. 1990. Electron microscopy. In Theory and Practice of Histological Techniques (ed. Bancroft, J.D. and Stevens, A.) pp. 525- 562. Edinburgh: Churchil Livingstone.

19. Samuelson DA. 2007. Textbook of Veterinary Histology. Saunders, an imprint of Elsevier Inc.

20. Shearman DJC, Muir AR. 1960. Observations on the secretory cycle of goblet cells. Quart. J. exp. Physiol., 45, 337-342.

21. Specian RD, Oliver MG. 1991. Functional biology of intestinal goblet cells. Am. J. Physiol. 260 (2Pt 1): C 183- 93.

22. Taylor $A B$, Anderson JH. 1972. Scanning electron microscope observations of mammalian intestinal villi, intervillus floor and crypt tubules. Micron. 3, 430-453.

23. Wischnitzer S. 1960. The ultrastructure of the nucleus and nucleocytoplasmic relations. Int. Rev. Cytol., 10, 137-162.

24. Yagil R, Zagorski O, Van Creveld C. 1994. Science and camels milk production (some keys for nutrition and Marketing/Dromadaires et chameaux, animaux laitiers. Actes du colloque, (24-26), Nouakchott, Mauritania, CIRAD.

25. Yu B, Chiou PWS. 1997. The morphological changes of intestinal mucosa in growing rabbits. Laboratory animals. 31, 254- 263. 